\title{
Pontos de Convergência entre o Inferir e o Argumentar ${ }^{1}$
}

\author{
Angela Santa-Clara \\ Alina Galvão Spinilloº \\ Universidade Federal de Pernambuco
}

\begin{abstract}
RESUMO - Inferir e argumentar são processos cognitivos e lingüísticos da maior relevância. Apesar de distintos, o inferir e o argumentar apresentam pontos de convergência que indicam haver uma relação entre essas instâncias. Sem incorrer em aproximações conceitualmente desautorizadas e preservando as especificidades de cada um desses processos, o presente artigo procurou indicar alguns pontos de contato entre o inferir e o argumentar. Esses pontos, mais do que elementos discretos e independentes, se caracterizam por um conjunto de elementos contínuos e interdependentes que se complementam mutuamente, sendo eles: o envolvimento de premissas e conclusões, a natureza situacional, a natureza dialógica, e a previsão. O principal objetivo do artigo foi conduzir uma reflexão que interessa a estudiosos do campo da argumentação e da compreensão de textos, em particular, e a estudiosos da cognição humana, de maneira geral.
\end{abstract}

Palavras-chave: inferir; argumentar; pontos de convergência.

\section{Convergent Points between Inferring and Arguing}

\begin{abstract}
To infer and to argue are two very important cognitive and linguistic processes. Although distinct, these processes present convergent points, which indicate the existence of a relationship between them. Without going into conceptually nonauthorized approximations, and preserving the particularities of the two processes, the present paper attempted to indicate some of the convergent points between inferring and arguing. These points, rather than being discrete and independent elements, are characterised by a set of continuous and interdependent elements which complement each other, namely: the involvement of premises and conclusions, the situational nature, the dialogical nature and (iv) the prediction. The main aim of the paper was to reflect upon aspects which will be of interest to academics of the field of argumentation and to those dealing with text comprehension, and especially to those concerned with human cognition in general.
\end{abstract}

Key words: inference; argument; convergent points.

Inferir e argumentar são processos cognitivos e lingüísticos da maior relevância que apesar de distintos, são, em última análise, duas faces de um mesmo fenômeno: a interação humana por meio da linguagem. Embora, usualmente inferir seja uma atividade associada à compreensão de textos e argumentar à produção de textos, é possível estabelecer uma ponte entre essas duas instâncias. Pinto (1995), por exemplo, relacionou essas habilidades ao tecer considerações bastante pertinentes a respeito da natureza inferencial da argumentação, apontando que na argumentação, as justificativas para um ponto de vista correspondem a premissas e que aquele que argumenta deseja que o interlocutor, com base nessas premissas, chegue às mesmas conclusões que ele.

$\mathrm{O}$ presente artigo explora a possibilidade de identificar pontos de convergência entre inferir e argumentar, inserindo esta discussão em um cenário mais amplo do que aquele proposto por Pinto (1995). Enquanto o autor discute o inferir na argumentação, o presente artigo expande a discussão,

1 Agradecimentos: à CAPES pela bolsa concedida à primeira autora durante estudos de doutoramento na Pós-Graduação em Psicologia Cognitiva da Universidade Federal de Pernambuco, período em que foi elaborado o presente artigo.

2 Endereço: Universidade Federal de Pernambuco, Pós-Graduação em Psicologia Cognitiva, $\mathrm{CFCH}, 8^{\circ}$ andar, Cidade Universitária, Recife, PE, Brasil 50670-901.E-mail: spin@ufpe.br tomando o inferir no âmbito da compreensão de textos e não no interior da argumentação. Este cenário possibilitou uma análise mais diversificada a respeito das relações entre o inferir e o argumentar. Antes, porém, de apresentar os pontos de convergência identificados, torna-se necessário caracterizar, ainda que de forma breve, a natureza dessas instâncias.

\section{As inferências e a compreensão de textos}

Compreender textos ${ }^{3}$ é fenômeno que envolve fatores de natureza lingüística, cognitiva, entre outros. Os fatores lingüísticos referem-se aos aspectos sintáticos, semânticos, lexicais e à habilidade de decodificação (quando textos escritos). Os fatores cognitivos, por sua vez, referem-se à memória de trabalho, às estratégias de monitoramento, à capacidade de integrar informações (e.g., Oakhill \& Yuill, 1996; Perfetti, Marron \& Foltz, 1996; Yuill \& Oakhill, 1991). Oakhill e Yuill (1996) agrupam esses fatores sob a denominação de processos de baixo nível (decodificação, reconhecimento de palavras e memória de trabalho) e processos de alto nível (inferências e monitoramento).

3 Como na compreensão os textos podem ser tanto orais como escritos, no presente artigo são feitas referências ao indivíduo receptor do texto como ouvinte ou como leitor. 
As inferências são apontadas como fator crucial no processo de compreensão, assumindo papel de destaque tanto nos modelos teóricos (Britton \& Graesser, 1996; Kintsch, 1998) como nas pesquisas conduzidas na área (Perfetti, Marron \& Foltz, 1996; Yuill \& Oakhill, 1991).

O Modelo de Construção-Integração proposto por Kintsch (1998), por exemplo, envolve o conhecimento de mundo do receptor do texto, os elementos textuais e a interação entre estes aspectos. De forma breve, esse modelo pressupõe dois componentes: o texto-base e o modelo situacional. $\mathrm{O}$ textobase se refere aos elementos explícitos no texto (conteúdo e forma lingüística), sendo definido como uma rede de proposições integradas. O modelo situacional, por sua vez, envolve as elaborações que o leitor realiza a partir dos seus conhecimentos lingüísticos, experiências e conhecimento de mundo. Em resumo, a elaboração de um modelo situacional está diretamente ligada à construção de inferências.

De maneira geral, estabelecer inferências é atividade cognitiva responsável pela formação de sentidos e de uma representação mental organizada e coerente do texto, resgatando a não explicitude das informações nele veiculadas. Uma vez que nem tudo no texto está explicitado e a compreensão não se restringe à mera extração de informações nele depositadas, o estabelecimento de inferências torna-se essencial na compreensão de textos (orais ou escritos). É através delas que as informações textuais e as informações derivadas do conhecimento de mundo do receptor do texto (leitor ou ouvinte) se integram e se conectam em uma representação mental coerente. De acordo com o Modelo de ConstruçãoIntegração (CI) de Kintsch, a representação mental resulta da construção de significados em cada passagem do texto e da integração entre as diversas informações textuais acrescidas e relacionadas ao conhecimento de mundo do indivíduo (e.g., Brandão \& Spinillo, 1998; Graesser, Singer \& Trabasso, 1994; Kintsch, 1998; Marcuschi, 1985, 1996; Oakhill \& Cain, 2004; Sampaio \& Spinillo, 1986; Mahon, 2002; Vidal Abarca \& Rico, 2003; Yuill \& Oakhill, 1991).

Conscientes do papel desempenhado pelo texto e pelos conhecimentos prévios do indivíduo, estudiosos da área consideram as inferências como intratextuais e extratextuais (Graesser \& Zwann, 1995; Mahon, 2002; Vidal Abarca \& Rico, 2003). As primeiras referem-se a informações geradas a partir da conexão de idéias veiculadas no texto; enquanto as inferências extratextuais são geradas a partir de uma conexão entre uma idéia veiculada no texto e o conhecimento de mundo do receptor do texto. As inferências intratextuais são geradas a partir das relações entre idéias sucessivas presentes no texto, permitindo, assim, explicitar o que estava implicitamente veiculado no texto. As inferências extratextuais, por sua vez, derivam-se das relações entre idéias presentes no texto e idéias relativas ao conhecimento prévio do indivíduo que foi acionado pelo texto.

Portanto, inferir resulta de um processo de construção, em que a integração das informações textuais engloba todo o texto e se associa a recortes do conhecimento de mundo do indivíduo relevantes para a compreensão de um dado texto. É exatamente o inferir que possibilita resgatar as informações não explícitas no texto, inclusive aquelas que ainda não foram veiculadas, como por exemplo, as inferências de previsão que consistem em criar hipóteses acerca do que virá a seguir em um texto (Feldman, Bruner, Renderer \& Spitzer, 1990; Feldman \& Kalmar, 2000; Mahon, 2002; Solé, 1998; Yuill \& Oakhill, 1991).

\section{A argumentação}

Na filosofia o estudo da argumentação é uma tradição e uma das formas mais profícuas dos raciocínios inerentes à própria atividade filosófica. Argumentar implica a capacidade de dialogar, de pensar, de analisar, de escolher e, em última análise, implica o comprometimento do indivíduo com os seus próprios argumentos.

Aristóteles foi o primeiro filósofo a expor uma teoria da argumentação, definindo-a como a arte de convencer. Buscando encontrar um meio termo entre as idéias de Platão e as dos Sofistas, definiu a Retórica como a arte de descobrir meios de persuasão para os vários argumentos. A intenção do filósofo era produzir uma comunicação mais eficiente para o Saber que ele considerava como algo que deveria ser adquirido. A Retórica, tornou-se, assim, a arte de falar de modo a persuadir/convencer diversas audiências de que uma dada opinião é preferível à sua oponente.

O objetivo principal de qualquer discurso argumentativo é provocar a adesão de uma dada audiência. Portanto, o discurso é sempre criado em função dessa audiência, pois antes de elaborar sua argumentação, o emissor precisa construir uma representação apropriada dessa audiência, de forma que possa realizar uma certa previsão sobre a possível adesão aos argumentos a que irão ser expostos. Obviamente, nem todos os argumentos provocarão a mesma adesão, e cada audiência requer uma estratégia argumentativa particular, de modo que o emissor possa apresentar, nos momentos certos, os argumentos mais apropriados de modo que o discurso venha a ser persuasivo. O fato é que, para argumentar, é necessário expor um conjunto de premissas (razões, provas, idéias) que justifiquem ou sustentem uma dada conclusão (ponto de vista ou tese).

Para que um discurso (ou segmento de discurso) seja considerado argumentativo é necessário que apresente uma organização e encadeamento lógico de argumentos de tal forma que a audiência possa acompanhar o raciocínio de quem o produz e, ao mesmo tempo, ser convencida a respeito da consistência da posição que está sendo defendida (Logos), e, eventualmente, tomar uma posição. Para que o discurso seja persuasivo é igualmente importante considerar, ainda, dois outros aspectos: 1) a credibilidade de quem argumenta (Ethos) e 2) as reações e opiniões da audiência diante da mensagem a ser veiculada (Pathos). Em outras palavras, o discurso argumentativo, tanto enfatiza a importância de quem elabora a argumentação, como também valoriza a audiência.

No âmbito da pesquisa psicológica, a qual vem ocupando um crescente espaço, nas últimas décadas, a argumentação tem sido definida como uma atividade discursiva de cunho social, intelectual e verbal que se realiza através da justificação e refutação de opiniões, visando o convencimento. Considerando sua natureza multifacetada, Leitão (2000) aponta cinco dimensões características da argumentação, a saber: verbal, dialógica, dialética, situada e epistêmica.

A dimensão verbal, se refere ao fato de que a argumentação se constitui no discurso, sendo, portanto, inerentemente 
verbal. A dimensão dialógica remete à sua constituição social e ao princípio das múltiplas vozes (heteroglossia), como caracterizado por Bakhtin (1995), a partir do qual se entende que a fala/ação humana pressupõe a expectativa de uma ação-resposta. É sempre em relação a um "outro", presente ou não, determinado ou indeterminado. Um diálogo interno de posições.

A existência de um tema controverso, ou passível de originar diferentes opiniões/pontos de vista, é a condição principal para que a argumentação se instale. Isto remete à sua dimensão dialética, ou seja, a consideração de existência de perspectivas contrárias (divergências reais ou pressupostas). A dimensão situada da argumentação se refere à sua sensibilidade ao contexto e às condições de produção.

Por último, tem-se a dimensão epistêmica que remete ao potencial transformador da argumentação, através do confronto de posições opostas que possibilita a emergência do "novo". As idéias de vários autores contemporâneos têm servido de suporte para esta reflexão. Miller (1987), por exemplo, assume uma perspectiva que ele próprio denomina interacionismo genético, a partir da qual a argumentação coletiva, que tem por meta alcançar soluções conjuntas para questões que exigem coordenação interindividual, é concebida como o único tipo de discurso que possui uma natureza intrinsecamente construtiva. Esta perspectiva se opõe diretamente ao que ele classifica de individualismo genético, uma vez que o desenvolvimento ocorre, prioritariamente através do desdobramento das estruturas no plano intrapsíquico. Tal oposição tem lugar, porque Miller acredita que a emergência do novo no desenvolvimento psicológico, só é possível mediante o confronto entre posições divergentes no plano interindividual.

A dimensão epistêmica tem sido particularmente explorada por Leitão (1999, 2000, 2001, no prelo), que considera a argumentação como um dos recursos racionais mais importantes para a constituição do conhecimento. Interessada em estudar como se produz a novidade a partir da argumentação, ou seja, o seu potencial como constitutiva do conhecimento, a autora desenvolveu uma unidade triádica de análise composta por: argumento (que engloba um ponto de vista e uma justificativa), contra-argumento (a oposição a um ponto de vista), e resposta (que é o aspecto psicológico do conceito). Para ela, a contra-argumentação é o mecanismo básico do desenvolvimento, visto que a oposição a um dado ponto de vista tem o poder de desencadear processos de revisão de posições ou crenças, permitindo ao indivíduo se mover rumo a novas perspectivas.

O modelo desenvolvido pela autora propõe a análise de enunciados do discurso, buscando identificar a presença de operações argumentativas (os componentes da unidade triádica), e explicitar as operações epistêmicas que se referem aos indicadores de mudança ou ampliação dos conceitos ou representações em questão. Essas últimas são observadas através das possíveis alterações do ponto de vista inicial, após o mesmo ter sofrido uma revisão mediante uma oposição.

\section{Pontos de convergência entre o inferir e o argumentar}

Uma vez definidos e caracterizados, ainda que de forma breve, o que vem a ser o inferir e o argumentar, e partindo da idéia de que é possível estabelecer uma ponte entre essas instâncias, procedeu-se a uma análise, sem pretender esgotar todas as possibilidades, em que foram identificados alguns pontos de convergência. Esses pontos, mais do que elementos discretos e independentes, se caracterizam por um conjunto de elementos contínuos e interdependentes que se complementam mutuamente, sendo eles: o envolvimento de premissas e conclusões, a natureza situacional, a natureza dialógica, e a previsão.

\section{O envolvimento de premissas e conclusões}

Inferir e argumentar requer lidar com premissas e suas conclusões. No caso da compreensão de textos, isso pode ser ilustrado com os exemplos a seguir:

Nessa espécie de ave, as fêmeas têm penas de várias cores no rabo, mas nunca têm penas azuis. O passarinho que ele havia ganhado de presente de seu tio tinha penas amarelas e azuis no rabo. Portanto aquela ave era um macho ${ }^{4}$.

Estabelecendo uma relação entre as premissas (primeira e segunda frases), o leitor deriva uma conclusão a respeito do sexo da ave: ela era um macho. Nesse exemplo, a conclusão advém de informações intratextuais. No entanto, pode ocorrer que as premissas envolvam informações extratextuais relativas ao conhecimento de mundo do leitor, como ilustrado na passagem a seguir, retirada de uma situação em sala de aula em que a professora trabalhava a compreensão de um texto ${ }^{5}$ escrito no quadro (Spinillo, 2002).

Tonico estava deitado folheando um livro. O local estava todo embaçado. De repente caiu sabonete nos seus olhos. Ele, depressa, procurou pegar a toalha. Então ele ouviu um barulho: ploft. Ah, não! O que iria dizer à sua professora? Ele ia ter que comprar um outro livro. Tonico esfregou os olhos e se sentiu melhor.

Professora: Em que parte da casa Tonico estava?

Aluno 1: No banheiro.

Professora: Cadê isso aqui no texto? Quais as partes do texto que deram essa idéia para você?

Aluno 1: Sabonete, toalha. Tudo isso tem no banheiro. Tava tomando banho de banheira.

Professora: Tá certo. Mas de banheira? Como sabe?

Aluno 2: Tá aqui tia (aponta para o texto), diz que tava deitado. No começo eu pensava que ele tava lendo na cama, mas ai disse sabonete, toalha. Ai tinha que ser tomando banho. E de banheira porque no chuveiro a gente fica de pé; não fica deitado não.

Assim, se tem sabonete e toalha (premissas), o local só pode ser o banheiro (conclusão). Esta conclusão é alcançada a partir da relação estabelecida entre as informações contidas no texto (intratextuais) e o conhecimento de mundo do leitor (extratextuais). O mesmo ocorre em relação à conclusão de que o menino estava tomando banho de banheira e não de chuveiro (premissa: o menino estava deitado).

No que se refere à argumentação, Pinto (1995) afirma que argumentar tem por objetivo gerar uma inferência na pessoa para quem o argumento é endereçado e não apenas

4 Texto elaborado para ilustrar a discussão que se segue.

5 Texto extraído de Yuill e Oakhill (1991, p. 182). 
gerar uma aceitação quanto à conclusão. Na argumentação, as premissas correspondem às justificativas para um ponto de vista ou a contra-argumentos levantados em resposta a contraargumentos que o endereçado levantou frente às justificativas apresentadas em defesa de um ponto de vista.

Ao passo que as premissas em um texto lido, por exemplo, permanecem relativamente constantes durante toda a leitura, na argumentação oral as premissas podem sofrer alterações à medida que novas informações vão surgindo no decorrer do discurso. Conforme Pinto (1995), as premissas apresentadas por aquele que argumenta servem de apoio para levar o receptor a chegar a uma conclusão em particular, ou seja, servem de base para gerar uma inferência no receptor, como ilustrado a seguir ${ }^{6}$ :

A mãe estava dirigindo, levando o filho para uma consulta médica. Durante o percurso Luís, o filho pequeno que segue de joelhos no banco de trás do veículo, fica brincando com os cabelos da mãe, fazendo cócegas em seu pescoço, perturbando, de certa forma, a sua atenção.

Mãe: Pare com isso, Luís!

Luís: E eu não gosto de tu?

... e continuou brincando com os cabelos da mãe, que nada mais disse. Apenas sorriu!

Ao dizer "E eu não gosto de tu?”, Luís está se opondo (contra-argumento) à ordem da mãe para que pare de brincar com ela enquanto está dirigindo. Esse contra-argumento, para ser aceito (ou compreendido), deve provocar a geração de uma inferência por parte da mãe. Deste modo, para tornar clara a inferência, a fala de Luís poderia ser reconstruída mais ou menos desta forma: Se eu gosto de tu (premissa), então eu posso continuar brincando com os seus cabelos e fazendo cócegas no seu pescoço! (conclusão).

As alterações pelas quais passam as premissas durante a argumentação oral podem ser entendidas quando se considera o papel do contra-argumento no discurso argumentativo. Leitão (2000) aponta quatro possíveis formas de reação aos contra-argumentos que implicam o grau de ajuste que vai ocorrer no ponto de vista inicial. Na reação de negação ao contra-argumento, o argumento inicial é preservado; na reação localizada, parte do contra-argumento é aceito, mas o argumento inicial permanece sem modificações; na reação integrada, do mesmo modo que na anterior, parte do contra-argumento é aceito e o argumento inicial é revisado; na reação de aceitação, o contra-argumento é totalmente incorporado e a posição inicial é abandonada.

Para Pinto (1995), argumentação é um convite à inferência, visto que o desejo daquele que argumenta é que seu interlocutor chegue às mesmas conclusões que ele a partir das premissas apresentadas. Argumentos são bem sucedidos quando as pessoas às quais eles são endereçados aceitam as conclusões com base em premissas. Argumentos fracassam quando o endereçado se recusa a aceitar as premissas ou quando aceita as premissas, porém, não deriva delas a conclusão.

No entanto, não há uma simples relação de lógica dedutiva na geração de uma conclusão, pois esta não depende apenas

6 Situação real vivenciada por uma das autoras, apresentada para ilustrar a discussão que se segue. das premissas apresentadas, mas também dos interesses, conhecimentos, crenças e motivações do receptor do texto ou daquele a quem um argumento é endereçado. Neste sentido, tanto argumentar como inferir são instâncias sensíveis ao contexto e à situação de produção em que ocorrem, como visto a seguir.

\section{A natureza situacional do inferir e do argumentar}

Como mencionado, inferir e argumentar são processos sensíveis ao contexto em que ocorrem. Em sendo assim, é pertinente o comentário de Bronckart (1999, p. 19) a respeito da linguagem de que "A forma e o conteúdo se fundem no discurso compreendido como fenômeno social: ele é social em todas as esferas de sua existência e em todos os seus elementos, desde a imagem auditiva até as estratificações semânticas mais abstratas". Ao defender a dimensão social da linguagem, o autor considera as contribuições oriundas da sociologia para estabelecer conexões entre as ações humanas em geral e as ações de linguagem em um dado momento histórico. Para ele o agir comunicativo (atividade de linguagem em funcionamento nos grupos humanos) dá forma ao social, ao mesmo tempo em que delimita as ações de indivíduos particulares, constituindo a pessoa enquanto agente psicológico. Assim, a tese central do interacionismo sócio-discursivo é que "(...) a ação constitui o resultado da apropriação, pelo organismo humano, das propriedades da atividade social mediada pela linguagem." (Bronckart, 1999, p. 42).

Como enfatizado por Leitão (1999, 2000, 2001, no prelo), a argumentação, enquanto um tipo particular de organização do discurso também possui essa natureza situacional. Os sentidos dos discursos são criados na interação, e sob a influência do momento histórico, social e cultural em que eles acontecem, não sendo possível se captar as intenções dos interlocutores de qualquer que seja o discurso, fora de sua situação de produção. Assim, na argumentação os sentidos são criados no discurso, isto é, constituídos na situação de produção.

No que concerne ao inferir na atividade de compreensão de textos, muitos dos sentidos do texto são atribuídos na interação do leitor com o texto (e conseqüentemente com o autor do texto), isto é, na situação de leitura. A situação de leitura remete ao que Solé (1998) denomina de propósitos da leitura. Segundo a autora, o leitor tenta, a partir dos objetivos que orientaram sua leitura, construir um significado do texto. Esses objetivos determinam a forma como o leitor se posiciona frente ao texto tanto em relação ao que é nele veiculado quanto em relação à maneira como a leitura se processa. Por exemplo, se o objetivo do indivíduo é ler um texto para obter uma informação específica, sua leitura será pontuada, seletiva no sentido de priorizar e focalizar determinadas passagens em detrimento de outras.

Se, por outro lado, o leitor tem por objetivo aprender sobre o ponto de vista do autor do texto a respeito de um tema, sua leitura será feita de forma mais minuciosa e exaustiva, percorrendo todo o texto. Percebe-se, portanto, que não se lê qualquer texto da mesma forma. Como os propósitos do leitor variam em relação a um texto, a geração de inferências irá variar em função desses propósitos, bem como a importância 
atribuída a determinadas idéias em detrimento de outras, embora essas idéias possam estar igualmente enfatizadas no texto. Em vista disso, decorre que há uma multiplicidade de significados possíveis para um mesmo texto que é passível de diversas alternativas de compreensão de acordo com aquilo que é inferido pelo leitor em uma dada situação.

A natureza situacional do inferir e do argumentar está relacionada à natureza dialógica que caracteriza ambos os fenômenos, como tratado a seguir.

\section{A natureza dialógica do inferir e do argumentar}

Em uma abordagem dialógica, a natureza da cognição humana é vista como dual, estando suas produções relacionadas tanto ao que é observado quanto ao próprio observador. $\mathrm{O}$ mesmo pode ser dito a respeito da linguagem, em geral, e de processos cognitivos particulares como o inferir e o argumentar.

De acordo com Bakhtin (1992, pp. 319-320),

O objeto do discurso, seja ele qual for, não é objeto do discurso pela primeira vez neste enunciado, e este locutor não é o primeiro a falar dele. O objeto, por assim dizer, já foi falado, controvertido, esclarecido e julgado de diversas maneiras, é o lugar onde se cruzam, se encontram e se separam diferentes pontos de vista, visões de mundo, tendências.

A esse respeito, Faraco (2003) comenta que o indivíduo, ao nascer, desembarca em um meio saturado de vozes em constantes e múltiplas relações dialógicas; compreendido como o complexo caldo da heteroglossia (complexo heterogêneo de vozes sociais). Tais vozes ou perspectivas são das mais diversas ordens: concordância e discordância, aceitação e recusa, convergência e divergência, harmonia e conflito etc. Mergulhado numa atmosfera heterogênea de relações e múltiplas dimensões da interação sócio-ideológica, o indivíduo assimila as vozes sociais (com suas inter-relações dialógicas), e vai se constituindo discursivamente.

(...) todo enunciado, além do objeto do seu teor, sempre responde (no sentido lato da palavra), de uma forma ou de outra, a enunciados de outros anteriores. (...) O enunciado está voltado não só para o seu objeto, mas também para o discurso de outro acerca desse objeto. A mais leve alusão ao enunciado do outro confere à fala um aspecto dialógico que nenhum tema constituído puramente pelo objeto poderia conferir-lhe. (Bakhtin, 1992, pp. 319-320).

A argumentação é um aspecto particular da natureza dialógica da linguagem, como propõe Leitão (2001) ao afirmar que a argumentação pode ser concebida como uma arena dialógica onde os indivíduos tentam fazer valer seus pontos de vista, lutando contra as posições divergentes dos outros. Pode-se dizer que situações discursivas são argumentativas quando pontos de vista são justificados e perspectivas alternativas são consideradas no sentido de mudar a perspectiva de uma audiência sobre um dado tópico. Esta ênfase no papel "do outro" é o que confere à argumentação sua dimensão dialógica?.

7 Leitão (2001) pontua a necessidade de superar a idéia equivocada que identifica diálogo com interação face-a-face, sugerindo que a atenção
A natureza dialógica do inferir, por sua vez, se expressa na interação estabelecida entre o leitor e o autor do texto através do texto que, na realidade, funciona como uma espécie de elemento intermediário entre esses interlocutores. Se por um lado, o autor durante o processo de produção precisa ter em mente um leitor imaginário; por outro lado, o leitor na tentativa de atribuir significado ao texto precisa ter em mente o produtor daquele texto. $\mathrm{O}$ inferir, portanto, pressupõe um diálogo entre o autor e o receptor com vistas à construção do significado do texto.

Segundo Marcuschi (1996), o texto é algo inacabado que será concluído pelo leitor. O autor e leitor estabelecem uma co-autoria de maneira que o autor produz parcialmente o texto, enquanto o leitor o completa. Como o texto não traz em si um único sentido, os seus possíveis sentidos são co-construídos através de uma relação dialética entre o conhecimento de mundo do leitor e o significado inicialmente pretendido pelo autor ${ }^{8}$.

Se a heteroglossia na argumentação se refere a posições opostas, na compreensão de textos, a heteroglossia se refere à multiplicidade de sentidos que podem ser inferidos a partir do conhecimento de mundo do leitor. Essa heteroglossia decorre da natureza dialógica do inferir e do argumentar, como também decorre dessa natureza dialógica o fato da previsão estar envolvida nessas duas instâncias.

\section{A previsão no inferir e no argumentar}

Como mencionado, o principal objetivo de qualquer discurso argumentativo é o convencimento de uma dada audiência em relação a um determinado ponto de vista. Neste sentido, o discurso argumentativo se configura em função dessa audiência, visto que o emissor precisa fazer previsões a respeito de sua audiência: dos seus pontos de vista, das justificativas que sustentam suas posições e das possíveis reações que pode apresentar (contra-argumentos) frente ao ponto de vista que o emissor deseja defender. Assim, com vista à adesão, o emissor necessita construir uma representação apropriada dessa audiência e prever, ainda, movimentos de seus interlocutores que concerne às reações que podem apresentar durante a argumentação. Tomemos o exemplo9 a seguir:

seja direcionada para os mecanismos dialógicos que operam na argumentação seja em situações de interação face-a-face (conversações), em situações monológicas (produção escrita), ou até mesmo em situações de argumentação do indivíduo consigo próprio. Um oponente, seja ele real ou virtual, está sempre interagindo na argumentação. Para isso é preciso que o diálogo seja considerado uma visão epistemológica particular, a partir da qual só se podem entender as ações de uma pessoa na sua relação com o ambiente social no qual elas emergem e em relação às ações dos outros.

8 Embora as inferências permitam flexibilidade e liberdade no processo de compreensão, há direcionamentos estabelecidos pelo próprio texto que precisam ser considerados para que não sejam feitas compreensões incorretas. Assim, apesar do caráter polissêmico e a pluralidade de significações possíveis num texto, não se pode inferir qualquer coisa, pois existem inferências desautorizadas e incoerentes que vão de encontro ao que é tratado no texto (Marcuschi, 1996; Mahon, 2002).

9 Exemplo extraído do corpus da Dissertação de Mestrado de Ferreira (2005), a quem agradecemos. 
Hora do almoço. A mãe coloca torta de galinha no prato de July, menina de dois anos e sete meses. Por não gostar da torta, ela tenta encerrar a refeição pedindo à mãe para ir ao parquinho.

July: Eu vou pro parquinho (olhando pra câmera). Tem maruim não. (balançando a cabeça negativamente).

A menina tem alergia à picada do inseto e usa sempre repelente.

Na fala da criança há uma conduta opositiva de antecipação de oposição à própria posição: "Eu vou pro parquinho". Em outras palavras, July antecipa uma possível objeção da mãe: "não vai porque tem maruim", à sua posição, quando diz: "tem maruim não". A fala de July responde, antecipadamente, à negativa da mãe, descartando um contra-argumento, ainda não expresso.

De forma análoga às previsões que precisam ser feitas pelo emissor frente a uma dada audiência, o autor de um texto também precisa fazer previsões em relação àquele a quem seu texto é endereçado. Com vistas a fazer-se entender, mesmo ciente da multiplicidade de sentidos que seu texto possa vir a suscitar, o autor durante o processo de produção precisa ter em mente um leitor imaginário: suas características, seu conhecimento de mundo, seus propósitos de leitura.

No entanto, a necessidade de fazer previsões também caracteriza o papel do leitor do texto. De acordo com Solé, (1998, p. 119), a previsão “(...) consiste em estabelecer hipóteses ajustadas e razoáveis sobre o que será encontrado no texto, baseando-se na interpretação que está sendo construída sobre o que já se leu e sobre a bagagem de conhecimentos e experiências do leitor", como ilustra o exemplo a seguir, retirado de uma situação em sala de aula com um texto escrito $^{10}$ no quadro (Spinillo, 2002):

Gilberto ganhou uma capa, um par de galochas e um guarda-chuva. Ele queria usar o presente. Para isso, queria um dia de chuva. Finalmente, após muitos dias de espera, o céu amanheceu coberto de nuvens cinzentas e pesadas. Gilberto vestiu a capa, calçou as galochas, abriu o guardachuva e foi para a calçada. A mamãe preveniu: "Cuidado, filhote, o que vem aí não é chuva. É uma terrivel tempestade!". O vento não estava de brincadeira. Soprava forte, que só vendo! De repente, soprou tão forte que as bordas do guarda-chuva se voltaram para cima. E a chuva molhou os cabelos, o rosto, a roupa de Gilberto, que entrou correndo em casa. A mamãe trocou a roupa de Gilberto e secou os cabelos dele. Mas não conseguiu secar-lhe o rosto, pois uma chuva de pinguinhos caía dos olhos do menino. Ele chorava por causa do guarda-chuva estragado. Então, ela falou baixinho, no ouvido de Gilberto. E um sorriso iluminou o rostinho triste.

Professora: O que você acha que a mãe de Gilberto disse para ele?

Aluno 1: Eu acho que a mãe dele vai dar outro guardachuva novo pra ele.

Professora: Por que você pensa assim?

Aluno 1: Porque ele queria ter um guarda-chuva. Aquele se acabou todo. Aí a mãe tinha dinheiro e ia comprar outro. Ele ficava feliz de novo.

10 Texto retirado do livro didático de Zélia Almeida, A Conquista da Linguagem - Estudo e Produção de Textos (Livro 2), Editora Dimensão.
Aluno 2: A mãe dele vai dar um chocolate pra ele comer.

Professora: Por que você acha isso?

Aluno 2: Chocolate é bom. Ele come e esquece do guarda-chuva. E pára de chorar.

Aluno 3: Eu acho que ela disse 'eu te amo meu filho'.

Professora: Por que você acha isso?

Aluno 3: Porque ai ele ia parar de chorar por causa que ela amava ele.

Ao integrar as informações entre partes do texto e entre o texto e seu conhecimento de mundo, o leitor faz previsões ${ }^{11}$, antecipando fatos e criando expectativas a respeito do que virá a seguir. Se algo veiculado no texto vai de encontro às antecipações feitas, o leitor re-elabora sua interpretação sobre todo o texto ou sobre partes dele. Assim, as inferências estabelecidas estão em constante re-elaboração, podendo ser alteradas no decorrer da interação com o texto.

Assim, o inferir e o argumentar envolvem previsões que antecipam fatos e permitem re-elaborações antes e durante a interação dos interlocutores. As previsões ilustram a permanente elaboração e re-elaboração por parte de quem argumenta e de quem estabelece inferências.

\section{Considerações Finais}

Aparentemente distintos, o inferir e o argumentar apresentam pontos de convergência que indicam a possibilidade de uma aproximação entre essas instâncias da comunicação e da cognição humanas. Sem incorrer em aproximações conceitualmente desautorizadas e preservando suas especificidades, o presente artigo procurou indicar alguns pontos de contato entre o inferir e o argumentar com o objetivo de ampliar a reflexão conduzida por Pinto (1995). O autor trata as relações entre argumentos e inferências a partir da natureza inferencial do argumentar, definindo inferência como “(...) ato ou evento mental no qual a pessoa deriva uma conclusão a partir de premissas, ou chega a uma conclusão com base em um conjunto de evidências." (Pinto, 1995, p. 271). No presente artigo, ao inserir as inferências no âmbito da compreensão de textos, amplia-se a concepção de inferência, abrindo espaço para a possibilidade de se identificar pontos de convergência mais amplos e diversificados do que aqueles tratados por Pinto.

Entendidos como atividades em constante re-elaboração, inferir e argumentar são processos lingüísticos e cognitivos da maior relevância que têm sido objeto de estudo no âmbito da psicologia cognitiva e da psicolingüíistica. Duas perspectivas, dentre outras, podem ser identificadas a respeito dos estudos nesta área: aprender a inferir e a argumentar, e o inferir e o argumentar para aprender.

Pesquisas inseridas no primeiro grupo examinam a possibilidade de desenvolver habilidades inferenciais e argumentativas. No que concerne à capacidade de estabelecer inferências, diversos autores consideram que compreender

11 Como a previsão só pode ser feita antes ou durante a leitura de um texto e não após, os pesquisadores criaram um recurso metodológico fundamental para investigar a capacidade de fazer inferências de previsão: apresentar textos de forma interrompida (Feldman \& cols., 1990; Mahon, 2002; Spinillo, 2002). 
textos, no sentido de inferir, é um dos aspectos básicos e mais representativos do domínio do uso da língua. O mesmo pode ser dito a respeito da capacidade de produzir textos argumentativos e a respeito do desenvolvimento da capacidade de argumentar. Assim, para se transformar em um usuário competente da língua materna, o indivíduo precisa aprender a estabelecer inferências na compreensão de textos (e.g., Marcuschi, 1996; Solé, 1998; Spinillo, 2002; Yuill \& Oakhill, 1991; Serra \& Oller, 2003) e aprender a argumentar (e.g., Coirier, 1996; Coirier, Andriessen \& Chanquoy, 1999; Ferreira, 2005; Golder \& Coirier, 1994; Leitão, 1999, 2000, 2001, no prelo; Rosenblat, 2005).

Pesquisas inseridas na outra perspectiva consideram o inferir e o argumentar relevantes na construção do conhecimento, sendo ambos entendidos como instrumentos para a aprendizagem de algo e não mais eles próprios como objetos de aprendizagem em si mesmos. No caso da compreensão de textos, é necessário ensinar a compreender textos para aprender, por exemplo, os conteúdos das disciplinas escolares em todos os seus segmentos. O processo inferencial, portanto, permite que o indivíduo seja capaz de buscar informações e aprender sobre diversos conteúdos a partir da leitura de textos. O leitor experiente não apenas estabelece inferências a partir de um dado texto como também é capaz de estabelecer relações complexas entre textos sobre um mesmo tema, tratando-os com se fossem premissas que geram conclusões sobre o tema em foco. No que tange à argumentação, surge o que os autores têm denominado intervenção argumentativa, definida como um conjunto de ações discursivas a serem desenvolvidas pelo professor, a fim de estimular o processo de argumentação em sala de aula com vistas à aprendizagem de algum conteúdo escolar (De Chiaro \& Leitão, 2005; Fernandes, 2002). Neste sentido, inferir e argumentar são postos a serviço da aprendizagem.

Para concluir, além de pontos de convergência entre o inferir e o argumentar, ambas as instâncias podem ser elas próprias objeto de aprendizagem como também instrumento de aprendizagem; destacando-se, assim, a relevância do inferir e do argumentar do ponto de vista psicológico, lingüístico e educacional.

\section{Referências}

Bakhtin, M. N. (1992). Estética da criação verbal. São Paulo: Editora Martins Fontes.

Bakhtin, M. N. (1995). Marxismo e Filosofia da Linguagem. São Paulo: Editora Hucitec.

Brandão, A. C .P. \& Spinillo, A. G. (1998). Aspectos gerais e específicos na compreensão de textos. Psicologia: Reflexão $e$ Crítica, 11(2), 253-272.

Britton, B. K. \& Graesser, A. C. (1996). Models of understanding text. Mahwah: Lawrence Erlbaum Associates.

Bronckart, J. (1999). Atividade de linguagem, textos e discursos: Por um interacionismo sócio-discursivo. São Paulo: Editora Educ.

Coirier, P. (1996). Composing argumentative texts: Cognitive and/ or textual complexity. Em C. Rijlaarrsdam; H. van der Bergh \& M. Cousijn (Orgs.), Theories, models and methodology in writing research (pp. 317-337). Amsterdam: Amsterdam University Press.
Coirier, P.; Andriessen, J. \& Chanquoy, L. (1999). From planning to translating: The specificity of argumentative writing. Em J. Andriessen \& P. Corier (Orgs.), Studies in writing. Foudations of argumentative text processing (pp. 1-28). Amsterdam: Amsterdam University Press.

De Chiaro, S. \& Leitão. S. (2005). O papel do professor na construção discursiva da argumentação em sala de aula. Psicologia Reflexão e Crítica.

Faraco, C. A. (2003). Linguagem \& diálogo: As idéias lingüísticas do círculo de Bakhtin. Curitiba: Criar Edições.

Feldman, C. F.; Bruner, J. S.; Renderer, B. \& Spitzer, S. (1990). Narrative comprehension. Em B. Britton \& A. Pellegrini (Orgs.), Narrative thought and narrative language (pp. 1-78). Hillsdale: Lawrence Erlbaum Associates

Feldman, C. F. \& Kalmar, D. A. (2000). Algumas implicações educacionais dos modelos mentais baseados em gêneros: A cognição interpretativa da compreensão de textos. Em D.R. Olson \& N. Torrance (Orgs.); Educação e desenvolvimento humano (pp. 360-380). Porto Alegre: Artmed.

Fernandes, P. M. (2002). Argumentação na sala de aula: construção de conhecimentos numa sala de aula de ciências. Dissertação de Mestrado, Universidade Federal de Pernambuco, Recife.

Ferreira, A. P. (2005). O desenvolvimento de condutas opositivas em crianças: Antecipação de posições contrárias. Dissertação de Mestrado, Universidade Federal de Pernambuco, Recife.

Golder, C. \& Coirier, P. (1994). Argumentative text writing: Developmental trends. Discurse Processes, 18, 187-210.

Graesser, A. C.; Singer, M. \& Trabasso, T. (1994). Constructing inferences during narrative text comprehension. Psychological Review, 101(3), 371-395.

Graesser, A. C. \& Zwaan, R. A. (1995). Inference generation and the construction of situation models. Em C. A. Weaver; S. Mannes \& C. R. Fletcher (Orgs.), Discourse comprehension: Essays in honor of Walter Kintsch (pp. 117-139). Hillsdale: Lawrence Erlbaum Associates.

Kintsch, W. (1998). Comprehension: A paradigm for cognition. Cambridge: University Press.

Leitão, S. (1999). Contribuições dos estudos da argumentação a uma análise psicológica de processos de construção de conhecimento em sala de aula. Arquivos Brasileiros de Psicologia, 1, 91109.

Leitão, S. (2000). The potential of argument in knowledge building. Human Development, 43, 332-360.

Leitão, S. (2001). Analyzing changes in view during argumentation: A quest for for method. Forum Qualitative Szialforschung / Forum: Social Resaerch, 2(3). Retirado em 31.08.2004, do [Online Journal], http://qualitative-research.net/fqs-eng.htm.

Leitão, S. (no prelo). Arguing and learning. Em C. Lightfoot, M. C. D. P. Lyra \& J. Valsiner (Orgs.), Advances in Child Development within Culturally Structured Environments: Challenges and strategies for studying human development in cultural contexts. Westport: Greenwood Publishing Group.

Mahon, E. R. (2002). Compreensão de texto: análise das inferências através de uma metodologia on-line. Dissertação de Mestrado em Psicologia Cognitva, Universidade Federal de Pernambuco, Recife.

Marcuschi, L. A. (1985). Leitura como processo inferencial num universo cultural-cognitivo. Leitura: Teoria e Prática, 4, 1-14.

Marcuschi, L. A. (1996). Exercícios de Compreensão ou Copiação nos Manuais de ensino da Língua? Em Aberto, 69, 64-82. 
Miller, M. (1897). Argumentation and cognition. Em M. Hickmann (Org.). Social and functional approaches to language and thought (pp. 225-250). New York: Academic Press.

Oakhill, J. \& Cain, K. (2004). The development of comprehension skills. Em T. Nunes \& P. Bryant (Orgs.), Handbook of children's literacy (pp. 155-180). London: Kluwer Academic Publishers.

Oakhill, J. \& Yuill, N. (1996). Higher order factors in comprehension disability: Processes and remediation. Em C. Cornoldi \& J. Oakhill (Orgs.), Reading comprehension difficulties: Processes and intervention. (pp. 69-92). Mahwah: Lawrence Erlbaum Associates.

Perfetti, C. A.; Marron, M. A. \& Foltz, P. W. (1996). Sources of comprehension failure: theoretical perspectives and case studies. Em C. Cornoldi \& J. Oakhill (Orgs.), Reading comprehension difficulties: Processes and intervention. (pp. 137-165). Mahwah: Lawrence Earlbaum Associates.

Pinto, R. C. (1995). The relation of argument to inference. Em F. H. Van Eemeren; R. Grootendorst; J. A. Blair \& C. A. Willard (Orgs.), Perspectives and approaches. (pp.271-286). Amsterdam: International Centre for the Study of Argumentation.

Rosenblat, E. (2005). Critérios para a construção de uma seqüência didática no ensino dos discursos argumentativos. Em R. Rojo (Org.), A prática de linguagem em sala de aula: Praticando os PCNs. (pp.185-201). Campinas: Mercado de Letras.
Sampaio M. C. H. \& Spinillo, A. G. (1986). Compreensão de narrativa: inferências pragmático-culturais. Cadernos de Estudos Sociais, 2(2), 529-541.

Serra, J. \& Oller, C. (2003). Estratégias de leitura e compreensão o texto no ensino fundamental e médio. Em A. Teberosky; C. Oller \& col. (Orgs.), Compreensão de leitura: A língua como procedimento. (pp. 35-44). Porto Alegre: Artmed.

Solé, I. (1998). Estratégias de leitura. Porto Alegre: Artmed.

Spinillo, A. G. (2002). Compreensão de textos em crianças: Um estudo de intervenção (relatório técnico de pesquisa). Recife: $\mathrm{UFPE} / \mathrm{CNPq}$.

Vidal-Abarca, E. \& Rico, G.M. (2003). Por que os textos são tão difíceis de compreender? As inferências são a resposta. Em A. Teberosky; C. Oller \& cols. (Orgs.), Compreensão de leitura: A língua como procedimento. (pp. 139-154). Porto Alegre: Artmed.

Yuill, N. \& Oakhill, J. (1991). Children's problems in text comprehension: An experimental investigation. Cambridge: Cambridge University Press.

\section{ASSINATURA PARA INSTITUIÇÕES}

Assinaturas de Psicologia: Teoria e Pesquisa podem ser solicitadas diretamente à: Secretaria de Divulgação Revista Psicologia: Teoria e Pesquisa Instituto de Psicologia, Universidade de Brasília 70910-900 Brasília, DF, Brasil.

O valor da assinatura anual é $\mathrm{R} \$ 98,00$. Número avulso para assinantes custa $R \$ 26,00$ e número antigo $R$ \$20,00. Número avulso para não assinantes custa $\mathrm{R} \$ 48,00$. Valores sujeitos a atualização. 